\title{
2 Tolerating religious pluralism?
}

\section{Freedom of religion as historical abstraction}

At the beginning of the 19th century, freedom of religion was no self-evident matter, and nor had it been in the preceding centuries. Religious doctrines and practices that diverged from the dominant and often state-privileged practice of religion might be tolerated in some places, but parity between religions or religious communities was a rarity.

Until the 1790s, there were no states that practised complete religious freedom. The United States' Constitution was amended in 1791 to prevent the restriction of religious freedom by federal authorities, but it was not binding on the respective states; there, toleration was fickle. The French Revolution brought what had historically been a highly anti-Protestant French state to the forefront when it came to religious freedom, but for a long time, this was an exception. A number of religious communities were tolerated in the Netherlands, but until the establishment of the Batavian Republic in 1795 - in the shadow of the French Revolution and notably under French domination - their freedoms were limited and subordinated to a privileged Calvinist church. In England, Protestant dissenters had received permission to practise their religion in 1689, albeit with restrictions and without being granted full political rights before $1828 .^{1}$ Catholics were accorded limited permission for the public exercise of their religion in 1791, but it was not until 1829 that they were given the right to sit in the UK Parliament. ${ }^{2}$ Prior to that, Catholics were for all practical purposes excluded from public life in Britain.

The free practice of religion was, therefore, seldom a constitutional right, but in some cases dispensations were granted by sovereigns or other political powers. As such, the same dispensations could also be rescinded, and certain religious practices could be circumscribed or prohibited at whim. History is replete with just such examples of this.

In places where they were permitted entry, Jews in particular experienced very little in the way of predictable legal conditions. This is exemplified not only by the expulsion of Sephardic Jews from the Iberian Peninsula beginning

1 Justin Champion, "Toleration and Citizenship in Enlightenment England: John Toland and the Naturalization of the Jews, 1714-1753," in Toleration in Enlightenment Europe, ed. Ole Peter Grell and Roy Porter (Cambridge: Cambridge University Press, 2000), $133 \mathrm{ff}$.

2 Ursula Henriques, Religious Toleration in England 1787-1833 (London: Routledge and Kegan Paul, 2007 [1961]), $136 \mathrm{ff}$.

2 OpenAccess. () 2021 Frode Ulvund, published by De Gruyter. (cc) BY-NC-ND This work is licensed under the Creative Commons Attribution-NonCommercial-NoDerivatives 4.0 License.

https://doi.org/10.1515/9783110657760-004 
from the end of the 1400s, but also with states and cities that were relatively accommodating towards Jews. The Prussian capital of Berlin in the 18th century was an example of exactly that. ${ }^{3}$

One of the best-known examples concerns the Calvinist Protestants in France - the Huguenots. They were permitted to practise their religion following the edict issued by King Henry IV (1553-1610) in 1598 as a result of the religious wars of the period. With repetitive formulations of the type "we have permitted," the edict detailed specifically what the Huguenots were allowed to do, while at the same time, through formulations such as "we expressly forbid," it also revealed the extent of the permission's limits. In this way the edict clearly emphasised that the Huguenot's practice of religion was not a liberty, but an authorisation, an act of benevolence on the part of the monarch. By the end of the 1600s the Huguenots' permissions were gradually being curtailed, before Louis XIV (1638-1715) abolished the edict entirely in 1685. French Protestants were then given the choice of converting to Catholicism or leaving the country. In 1787, on the eve of the French Revolution and as an act of grace by the French absolute king, the Huguenots were again allowed to practise their religion.

As pointed out by historians Ole Peter Grell and Roy Porter in the anthology Toleration in Enlightenment Europe, in the Western world of the 18th century religious toleration was at best partial, and where granted often contested and subject to reversal. ${ }^{4}$ Religious politics during L'Ancien Régime - another name for Europe's pre-revolutionary and more or less feudal and autocratic society was based on dispensations, acts of grace issued by obliging sovereigns or other powers in positions to do so. Religious aberration could thus be tolerated, but not treated on an equal footing with the dominant or state religion. Religious persecution was therefore not necessarily controversial, and the idea of discriminating against or excluding religious groups could be viewed as an entirely legitimate policy.

\section{Tolerance and toleration}

The concepts of tolerance and toleration require clarification. In the English language, the two terms are distinguishable. Both have roots in the Latin tolerantia. Tolerance is usually defined by individual characteristics and virtues, as the four

3 For the changing legal status of Jews in Germany, see Moses Elon, The Pity of it All: A Portrait of Jews in Germany 1743-1933 (London: Penguin, 2004).

4 Ole Peter Grell and Roy Porter, eds., Toleration in Enlightenment Europe (Cambridge: Cambridge University Press, 2000), 1. 
cardinal virtues were understood from antiquity. Prudence, justice, temperance and courage were all virtues that characterised an individual's fundamentally positive and appealing qualities. Similarly, tolerance is understood as a virtue in moral terms, a positively charged inherent trait: an inclination or ability to be tolerant. Toleration is not a question of virtues, but rather of enduring something - i.e. a practice - one actually dislikes. ${ }^{5}$ This also implies that the noun toleration can be repurposed as a verb: to tolerate.

In Scandinavian languages and in a number of central European languages, there is no distinction between the nouns tolerance and toleration. This leads to a loss of nuance, since the English concept of toleration is thus something other than the more general Scandinavian toleranse. Religious politics is about practising toleration, or perhaps intoleration, in a pragmatic political context. Central to this book's theme, therefore, is how toleration has been practised by authorities at different levels, and what has shaped the boundaries of what could be tolerated.

Until the mid-18th century, toleration as a concept of action (Handlungsbegriff in German) was primarily applicable to the field of church politics, and concerned questions about permitting aberrant religious practices and teachings. According to church historian Gerhard Besier, it was not until after the century's midpoint that the term began to be applied to forms of freedom of conscience other than the religious. ${ }^{6}$ As such, toleration was for a long period closely tied to the religious sphere and a politico-religious discourse.

The literature discussing the concept of toleration is extensive, but there is an intersubjective consensus that the term comprises certain components. ${ }^{7}$ That which is to be tolerated must first give rise to an aversion, something that is disliked and to which one has clear and deeply held objections. Toleration is not, therefore, equivalent to indifference or passivity.

American philosopher Andrew Jason Cohen has discussed the term in several of his works. He underscores that neither is toleration an equal of pluralism in the form of enthusiastic endorsement of difference. ${ }^{8}$ Toleration does not apply to

5 See for example Michael Walzer, On Toleration (New Haven and London: Yale University Press, 1997), 8 ff.

6 Gerhard Besier, “XI. 'Toleranz’ als religionspolitischer Begriff im 17. und 18. Jahrhundert,” in Geschichtliche Grundbegriffe: Historisches Lexikon zur politisch-sozialen Sprache in Deutschland. Bind 6, ed. Otto Brunner, Werner Conze and Reinhart Koselleck (Stuttgart, Klett-Cotta, 1990), Chapter "Toleranz," $495 \mathrm{ff}$.

7 See Preston King, Toleration (New York: St. Martin’s Press, 1976). Rainer Forst, Toleration in Conflict: Past and Present (Cambridge: Cambridge University Press, 2013), $17 \mathrm{ff}$.

8 Andrew Jason Cohen, "What Toleration Is," Ethics, vol. 115, no. 1 (October 2004): $74 \mathrm{ff}$. 
that in which one has no involvement, yet nevertheless encourages or holds a positive view of. Nor is toleration necessarily the same as non-intervention. One can attempt to convince someone to change a practice one dislikes, yet permit or accept the practice after the attempt has failed.

Cohen therefore distinguishes between relativism and toleration. Toleration requires an acknowledgment or appreciation of one's own indulgence of an aversion, not an understanding that others' views or practices are "as good" as one's own. Toleration, then, primarily concerns self-restraint towards aversion.

At the same time, this displeasure must be tolerated voluntarily and not as a result of external coercion. Toleration is therefore the discretionary permitting of something to which one has an aversion. It is further noted that the boundaries of what is being tolerated are under continuous evaluation and are therefore also subject to change. Toleration can thus be rendered invalid, and a previously tolerated religious practice or doctrine can become considered intolerable, or vice versa.

In the sense that those who are tolerated are in a subordinate and vulnerable position in a hierarchy dominated by those who tolerate them, toleration thus emerges as being closely associated with hegemony and the exercise of power. This connection also allows Jürgen Habermas, for example, to define tolerance as a form of individual political virtue, while he reserves toleration for the legal permission granted by the state to practise a religion that deviates from the state's own. ${ }^{9}$ The individual's ability to tolerate (tolerance) is a virtue, while the practice of toleration is politics.

In such a power-oriented context, therefore, toleration and persecution are not polar opposites, but two different aspects of the same issue. In his work The Rights of Man from 1792, the British radical and political philosopher Thomas Paine (1737-1809) defined toleration as intolerance in disguise, concluding that both were markers of despotism. The French Constitution had abolished and renounced both toleration and intolerance as well as establishing universal human rights, he explained, continuing: "Toleration is not the opposite of Intolerance, but is the counterfeit of it. Both are despotisms." ${ }^{10}$ While one bestowed upon itself the right to grant freedom of conscience, the other conferred the right to deny it. One represented the pope with fire and flaming torches, the other the pope selling indulgences. One was church and state, the other church and commerce.

9 Jürgen Habermas, "Religious Tolerance: The Pacemaker for Cultural Rights," Philosophy, vol. 79, no. 307 (January 2004): 5.

10 Thomas Paine, Thomas Paine Reader, eds. M. Foot and I. Kamnick (Harmondsworth: Penguin, 1987), $231 \mathrm{f}$. 
Both toleration and persecution concern the dislike of something, but represent different reactions to the same aversion. Persecution is an attempt to eradicate or actively combat something one dislikes, while toleration is to withstand or endure suffering. One tolerates, for example, a religion in the same way one tolerates pain. And as with pain, toleration could also have its outer limit, a threshold beyond which the suffering became too great to endure.

Toleration therefore provides a framework for the exercise of religion. However, as long as it is only an expression of temporary dispensations, it does not provide a framework for religious freedom. Since it is granted as a form of favour by a hegemonic power and can be withdrawn at any time, it is, in the best case, a provisional religious freedom.

Toleration is not, therefore, a marker of parity or equality between religions or religious communities. In the first instance, this requires a clear constitutional codification of religious freedom and a balanced framework for the practice of religion. Then it becomes a liberty, and not merely a permitted - tolerated - activity. Only then will what German philosopher Rainer Forst describes as toleration's concept of permission be supplanted by a concept of respect, and freedom of religion established as a civil liberty. ${ }^{11}$

\section{The practice of toleration}

Freedom of religion as an idea is often linked to the Enlightenment era, and especially to canonical texts by John Locke (1632-1704) and Pierre Bayle (16471706), and later also Voltaire (1694-1778) and Moses Mendelssohn (17291786). Their ideas have traditionally been contrasted with the religious despotism and brutal persecutions of earlier periods - especially the Middle Ages - with their foundations in Catholicism, and inquisitions and burnings at the stake as their "pinnacle."

The American John Rawls, one of the most distinguished theorists within political philosophy in the latter part of the 20th century, implied that the growing practice of religious toleration was a necessary forerunner of modern liberalism: "The historical origin of political liberalism is the Reformation and its aftermath, with the long controversies over religious toleration in the sixteenth and seventeenth centuries." 12

11 Forst, Toleration in Conflict, $26 \mathrm{ff}$.

12 John Rawls, Political Liberalism (New York: Columbia University Press, 1996), xxvi. 
Religious toleration emerged as the midwife of an individualism that increasingly challenged the corporations and hierarchy of the time, and toleration was thus portrayed as a historical imperative for the emergence of individual rights and modern democracy.

Not just the influential book by Henry Kamen, The Rise of Toleration from the 1960s, but also the far more recent and widely read How the Idea of Religious Toleration Came to the West (2003) by Perez Zagorin, begin from just such a teleologically oriented narrative. ${ }^{13}$ For them, the Middle Ages were characterised by the Catholic Church's sanctioning and practice of religious persecution, including as a result the papist inquisition and the killing of countless Christians whom the Church declared to be heretics. The Reformation did not improve matters. On the contrary, the Protestant denominations and states were no less intolerant of "heretics" than the Catholic Church had been. According to Zagorin, it was the long and terrible history of Christianity's inhumanity in the face of religious pluralism that caused Voltaire to declare Christianity the most intolerant of all religions. $^{14}$

Zagorin writes that the evolution of religious toleration from the Enlightenment onwards has been long and complicated, but nevertheless fully characterised by a steady strengthening of the idea in Western consciousness, and by an ever-increasing recognition that toleration was a right for all individuals and religions. In his argument he refers to the fact that that toleration's gradual emergence and realisation in the body of laws and institutions was part of the Western evolution towards "political freedom, democracy, and - in the widest, least doctrinaire sense - toward a liberal society protective of individual rights." 15

American historian Jeffrey Collins argues that when it comes to liberalism, such a linear view essentially passes down an origin myth. In a historiographical review of recent research literature, he points to anachronistic problems in the narrative as well as to the use of religious toleration as a measure of the status of individual civil rights being questionable. ${ }^{16}$ The traditionally strong link between toleration and freedom of religion is criticised as presentist: It maintains an understanding of the concept of toleration that is based upon a modern and liberal context in which toleration is associated with liberties, and not with power or despotism.

13 Henry Kamen, The Rise of Toleration (New York: McGraw-Hill, 1967); Perez Zagorin, How the Idea of Toleration came to the West (Princeton: Princeton University Press, 2003).

14 Zagorin, How the Idea of Toleration, $2 \mathrm{f}$.

15 Zagorin, How the Idea of Toleration, $299 \mathrm{f}$.

16 Jeffrey R. Collins, "Redeeming the Enlightenment: New Histories of Religious Toleration," The Journal of Modern History, vol. 81, no. 3 (September 2009): 610. 
Collins shows how, in recent decades, greater emphasis has been placed on distinguishing between toleration as an idea and a practice, and also that toleration was practised in different ways and at different levels throughout the Middle Ages and up to the Enlightenment. The Reformation and the subsequent Age of Enlightenment, he argues, do not thus mark as great a dividing line in the emergence of a "civilised" and tolerant society as has often been portrayed.

Historian István Bejczy explains that the modern understanding of the concept of toleration is a product of recent times, especially of the Enlightenment. ${ }^{17}$ By way of conceptual historical analysis, he shows how the concept of tolerantia has shifted meaning in the period from antiquity to the modern age. While the classical and early Christian understanding of tolerantia emphasised the individual's endurance of affliction, in the Middle Ages the term was also given a social and political substance. In that period it stood for the indulgence of evil or harmful people (the immoral; heretics; heathens), exercised by people with power. Such forbearance was not an expression of benevolence or respect, but a calculated practice - a policy - whereby the permitting of sin was effected in order to prevent an even greater wrong or peril. Jews and Muslims could be tolerated to establish order; prostitutes could be tolerated to avoid rape and homosexuality. The benefits and pitfalls of tolerating were assessed alongside each other, and if the advantages were perceived to outweigh the disadvantages or the reluctance, toleration could be the outcome - yet those being tolerated provoked aversion all the same.

As a social and political concept, tolerantia was borrowed from the individual sphere, and both object and subject of toleration - the tolerated and those who tolerated - became collectivities. Thus, in many languages the term also gained a double meaning, both as a virtue and as a practice. The tolerated were groups of people who appeared to be an affliction on or danger to society, and the tolerating parties were no longer individuals, but institutions that exercised power on behalf of society. Tolerantia, in the sense of toleration, was therefore associated in the Middle Ages with political restraint characterised by the absence of - or, at least, restraint in the use of - disciplinary and corrective means of coercion on the part of the executive powers, since such an absence was politically opportune. ${ }^{18}$

Because toleration was about regulating hatred and not about respect or freedom, in the Middle Ages and for centuries to come this gave the term a det-

17 István Bejczy, “Tolerantia: A Medieval Concept,” Journal of the History of Ideas, vol. 58, no. 3 (July 1997): 365.

18 Bejczy, "Tolerantia," 368. 
rimental and derogatory resonance. Being intolerant was thus not necessarily viewed as a negative trait - rather the contrary, since toleration was associated with opportunism. In 1691, for example, French bishop Jacques Bossuet could proudly proclaim that Catholicism was the least tolerant of all religions and confessions, and as such was implicitly the least opportunistic. ${ }^{19}$

In the same year that Bejczys published his article, the anthology Beyond the Persecuting Society, edited by Cary Nederman and John Laursen, was also released. Here, Nederman argued that if medieval Christianity did not provide the framework for a fully open society evaluated on what she calls "post-Enlightenment standards," neither did it represent a closed and monolithic "persecuting society," as the period has often been portrayed..$^{20}$ A central thesis for the anthology is that toleration was present both as an idea and as a practice in the Middle Ages and in early modern times, and thus long before the Age of Enlightenment.

In Divided by Faith. Religious Conflict and the Practice of Toleration in Early Modern Europe, Benjamin Kaplan also confronted what he described as the myth of how toleration and liberalism emerged - that is, the story of how the idea of toleration was first formulated by the important and visionary Enlightenment thinkers, and later sustained and institutionalised by a few progressive sovereigns who had been enlightened by reason. ${ }^{21}$ Just as Norbert Elias presented his grand theory of the civilisation process as a change in mentality that initially took root in the elite and gradually spread to the masses, toleration's narrative has a similar linear evolution from persecution to toleration: first with a breakthrough among an elite, then with a dissemination to the general populace. Kaplan criticises this narrative as a product and heritage of the Enlightenment era and shows how toleration was practised by most people in their communities long before the Enlightenment. People of different religions or denominations largely lived their daily lives alongside one another - resorting neither to violence nor to persecution.

Local investigations, which shift the focus from central government legislation and policy to practices across a variety of urban and rural communities, substantiate Kaplan's portrayal of peaceful coexistence across religious divides

19 Alexandra Walsham, Charitable Hatred: Tolerance and Intolerance in England, 1500-1700 (New York: Manchester University Press, 2006), 5.

20 Cary J. Nederman, "Introduction: Discourse and Contexts of Tolerance in Medieval Europe," in Beyond the Persecuting Society: Religious Toleration Before the Enlightenment, ed. John C. Laursen and Cary J. Nederman (Philadelphia: University of Pennsylvania Press, 1997), 23.

21 Benjamin Kaplan, Divided by Faith: Religious Conflict and the Practice of Toleration in Early Modern Europe (Cambridge, MA: Belknap Press of Harvard University Press, 2007), 7. 
in several places. This happened not least because social order in the local community was in most people's interests. ${ }^{22}$ Thus, to a great extent, everyday toleration as a practice is also a social phenomenon, not just a political one.

In recent times it is not just the narrative of the lack of toleration before the Enlightenment that has encountered academic resistance among historians. Master narratives about the growth of toleration - from persecution to toleration and freedom - have also been contested and nuanced. This is particularly true of the representations of the Netherlands and America as the birthplaces and ports of refuge of religious freedom in a world that, in pre-revolutionary times, was otherwise encircled by religious regimentation and intolerance.

\section{The Netherlands and religious segregation}

The image of the Netherlands as a model of religious toleration arose in the aftermath of the split from Catholic Spain. In the Utrecht agreement of 1579, the rebel provinces agreed that every individual had the right to choose his or her own faith, and that no one should be persecuted on the basis of religion. In religious terms, especially in the 1600s, the provinces emerged as pluralistic societies, with the presence of Catholics, Lutherans, Calvinists, Arminianists, Anabaptists, Arianists, Quakers, Mennonites, Socinians, Jews and Turks, to name a few. For many, including Sephardic Jews (also referred to as conversos - converts) from the Iberian Peninsula and Huguenots from France, the Netherlands became a sanctuary.

Despite the 1579 agreement, the Dutch Republic became a primarily Calvinist state. Although not formally established as state church, the Calvinist Church (the Reformed Church) was closely linked to the Dutch state and referred to as the public church. The Calvinists were granted extensive ecclesiastical and civil privileges. The state funded the Calvinist Church and its pastors, and membership of the church was a requirement in order to enter government office and public posts in the country. ${ }^{23}$

Other denominations were tolerated to a greater or lesser degree, but with differing restrictions. Historian Ronnie Po-Chia Hsia characterises the Dutch Re-

22 See Walsham, Charitable Hatred, for a thorough discussion of how toleration was practised on a daily basis in the local community.

23 Ernestine van der Wall, "Toleration and Enlightenment in the Dutch Republic," in Ole Peter Grell and Roy Porter, Toleration in Enlightenment Europe (Cambridge: Cambridge University Press, 2000), 115. 
public as a confessionally pluralistic society with an intolerant official Calvinist Church that discriminated against Catholics, but one that was nevertheless distinguished by pragmatic religious toleration. ${ }^{24}$ According to Hsia, a strong civil state, especially in the province of Holland, was able to maintain the peace between a hegemonic Calvinist Church and other religious communities; religious pluralism was not based on individual rights and parity between religions, but on a "pillarised" society.

In sociological research, the concept of pillarisation (verzuilung) has been used, particularly since the 1960s, to describe Dutch society as being divided into four vertical pillars: one Protestant, one Catholic, one liberal and one socialist. ${ }^{25}$ These emerged almost as parallel societies with their own norms, practices, and public spheres relating to social discipline and key functions such as teaching, poor relief and care, and with little in the way of contact between pillars. In historical analyses, pillarisation is used as an analytical approach to describe the division of several separate religious communities, strictly overseen by civil authorities. ${ }^{26}$ As such, Dutch religious toleration has not historically been a project promoting integration, but has rather given rise to separate and distinctive social groupings or milieus.

In addition to such signs of the forming of corporations and the segregation of those denominations that lay beyond the privileged church, there were major local differences. Notions about the Netherlands are often derived from Amsterdam and to some extent the province of Holland. It was here that toleration stood firmest. Sephardic Jews mainly settled in Amsterdam, and the Jewish environment was less common beyond the commercial hub that the city became. The individual provinces had considerable latitude and regional authorities exercised varying degrees of toleration. The Reformed Church had a greater outlet for repressive attitudes in places such as Utrecht, Zwolle, Arnhem, Deventer and Nijmegen, cities in which the guilds had far more appreciable political influence than in Amsterdam. ${ }^{27}$ While Lutherans were allowed to build churches in Am-

24 Ronnie Po-Chia Hsia, "Introduction," in Calvinism and Religious Toleration in the Dutch Golden Age, ed. Ronnie P.-C. Hsia and Henk van Nierop (Cambridge University Press, 2002), 2.

25 Arendt Lijphart, The Politics of Accommodation: Pluralism and Democracy in the Netherlands (Berkeley, University of California Press, 1968).

26 Hsia, "Introduction," $3 \mathrm{ff}$. The concept of the "pillar society" in the context of history of religion was first employed by S. Groenveld in Huisgenoten de geloofs: Was de samenleving in de Republiek der Verenigde Nederlanden verzuild? (Hilversum: Verloren, 2002).

27 Maarten Praak, “The Politics of Intolerance: Citizenship and Religion in the Dutch Republic (Seventeenth to Eighteenth Centuries)," in Calvinism and Religious Toleration in the Dutch Golden Age, ed. Ronnie P.-C. Hsia and Henk van Nierop (Cambridge University Press, 2002). 
sterdam, until the 1790s it was difficult for their fellow worshipers in Leeuwarden to gain permission to practise religion in private. The province of Holland permitted Catholic priests in 1730, while they were banned in the province of Friesland until $1776 .^{28}$ However, there are cases of toleration being procured via the bribing of local officials, even in regions or periods with little formal toleration. $^{29}$

From the mid-1700s, grievances against restrictions on religious practice resulted not only in demands for increased toleration, but also for equality in religious matters. Such demands were met with considerable resistance. However, when revolutionary France invaded the Dutch Republic in 1795 and greatly contributed to the establishment of the Batavian Republic (1795-1806), the Calvinist Church's privileges were abolished; religious equality was introduced in the years 1795-1796. This was later codified in the constitutional laws of 1798 onwards. Religious freedom was thus instituted as a result of external compulsion.

\section{Agonising American pluralism}

Colonial North America was also pluralistic in the religious sense, and for many immigrants it was the very lack of toleration in Europe that acted as a driving force to emigrate across the Atlantic. However, as with the provinces and cities in the Netherlands, there were broad local variations in toleration's scope. The respective colonies were dominated by a variety of religious groups and denominations that were not necessarily inclined to tolerate aberrant religious practices. The colonies of New England, for example, were characterised by Puritans, Pennsylvania was dominated by Quakers, while Maryland was a Catholic enclave.

According to historian James Hutson, by the 1600s Massachusetts authorities had arrested and deported - or threatened to deport - members of just about every religious persuasion. ${ }^{30}$ Both Virginia and Massachusetts established deportation for Quakers, with the death penalty for those who returned. It was

28 Joke Spaans, "Religious Policies in the Seventeenth-Century Dutch Republic," in Calvinism and Religious Toleration in the Dutch Golden Age, ed. Ronnie P.-C. Hsia and Henk van Nierop (Cambridge University Press, 2002), 85.

29 Christine Kooi, "Paying Off the Sheriff: Strategies of Catholic Toleration in Golden Age Holland," in Calvinism and Religious Toleration in the Dutch Golden Age, ed. Ronnie P.-C. Hsia and Henk van Nierop (Cambridge University Press, 2002).

30 James H. Hutson, Church and the State in America: The First Two Centuries (Cambridge: Cambridge University Press, 2008), $16 \mathrm{f}$. 
for this reason that in Boston between 1659 and 1661, four Quakers were hanged. ${ }^{31}$

The Anglican Church was the official church in several colonies, especially in the south. In New England, the state churches were Congregational. It was not until the beginning of the 19th century that church and state were separated in all states, a process that was rounded out by Massachusetts's abolition of ties between the two as late as 1833.

In pluralistic America, Protestantism dominated completely, and the largely absent Catholicism was especially disliked and subjected to limited toleration and its adherents had their civil rights curtailed. Every year until the 1780s, Bostonians demonstrated their abhorrence of Catholicism and the pope on "Pope's Day." This was a tradition brought over from England as a reminder of the 1605 Gunpowder Plot, an event that was perceived as a plot to assassinate the English king initiated by the pope. Grotesque dummies of the pope were paraded contemptuously through the streets of Boston before finally being set on fire. In its report of the celebration in 1765, the Massachusetts Gazette explained that the mock-ups represented "the Pope, Devil, and several other Effigies signifying Tyranny, Oppression, Slavery."32

By the 1730s, most dissenter groups had gained the permission to private religious practice in the majority of the colonies, but were not accorded equal status. In many places, tolerated dissenters were excluded from civilian and military public service, and from attending universities. ${ }^{33}$ In colonial Virginia, dissenters had to apply for permission to give expression to their religious doctrines, and in Massachusetts, Quakers, Anglicans, and Baptists were put through something approximating a trail by fire in order to obtain official approval. Historian Chris Beneke writes that smaller, marginalised denominations experienced direct persecution in America all the way up to the final third of the 18th century. ${ }^{34}$

In practice this continued until the end of the 19th century, and anti-Catholicism and anti-Mormonism in particular provoked both popular and institutional

31 Hutson, Church and the State, 17.

32 Massachusetts Gazette 7 November 1765. Quoted here from http://www.celebrateboston.com/ intolerance/popes-day-1765.htm, accessed 25 August 2016.

33 Chris Beneke, Beyond Toleration: The Religious Origins of American Pluralism (Oxford: Oxford University Press, 2006), 6.

34 Beneke, Beyond Toleration, 6. 


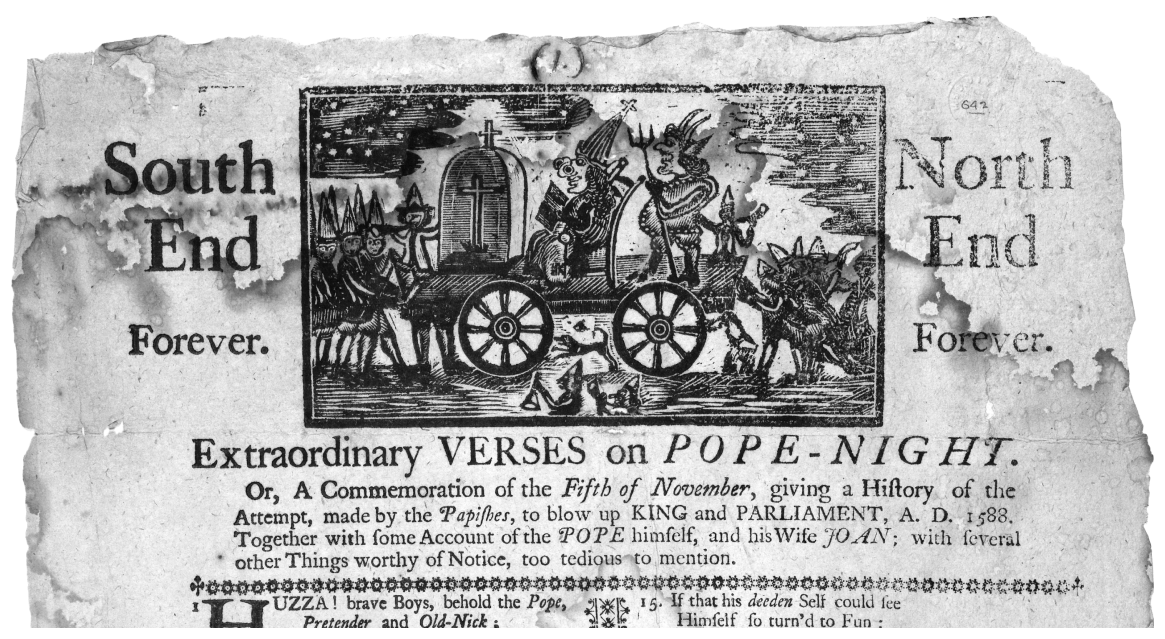

Figure 2.1: "Extraordinary verses on Pope-night. or, A commemoration of the fifth of November, giving a history of the attempt, made by the Papishes, to blow up King and Parliament, A.D. 1588." The sixth verse in this mockery: "See I how He Shakes his tot'ring Head And knocks his palsy Knees; A Proof He is the Scarlet Whore, And got the soul Disease." This pamphlet portrays the annual anti-Catholic parades in Boston on 5 November, in which effigies of the pope were carried around in the streets before they were set on fire. The parades ended after the independence in 1776, partly because the US was seeking support from Catholic France. The pamphlet seems to confuse the events of the Spanish Armada in 1588 and Guy Fawkes' (15701606) attempt to blow up the English parliament in 1605.

resistance and strife. ${ }^{35}$ This was in part intertwined with ethnic prejudice, especially against economically underprivileged Irish immigrants. ${ }^{36}$

From the 1760s, the practice of politically granted toleration was gradually supplanted by principles of equality and religious freedom. An illustrative change can be observed with the federal founding fathers George Mason (1725-1792) and James Madison (1751-1836) in 1776, as Virginia was preparing a new constitution. Mason first proposed that the state should ensure "the fullest toleration in the exercise of religion." However, on the suggestion of Madison,

35 J. Spencer Fluhman, 'A Peculiar People': Anti-Mormonism and the Making of Religion in Nineteenth-Century America (Chapel Hill: The University of North Carolina Press, 2012).

36 Owen Stanwood, “Catholics, Protestants, and the Clash of Civilizations in Early America," in The First Prejudice: Religious Tolerance and Intolerance in Early America, ed. Chris Beneke and Christopher S. Grenda. Early American Studies (Philadelphia, US: University of Pennsylvania Press, 2011), 219. See also W. Paul Reeve, Religion of a Different Color: Race and the Mormon Struggle for Whiteness (New York: Oxford University Press, 2015). 
who perceived toleration as mere dispensations for hierarchical subordinates and dissenting religions, "fullest toleration" was replaced by "free exercise of religion." ${ }^{37}$ In Virginia from then on, the free exercise of religion was no longer a permission, but declared a liberty.

The federal Constitution of 1787 , for which Madison was a key draftsman, and its amendment in 1791, outlawed discrimination on religious grounds in federal appointments and also introduced a prohibition on the establishment of a federal state church. This was, however, only binding on the federation, and state practice remained varied. Yet, with the exception of Connecticut, every state constitution contained wording regarding religious liberty by the end of the 1780s, although in some states these were limited to Christians or Protestants, and often appeared in the form of preambles that other legislation would, in practice, curtail. Some states also had limited civil rights for religious groups other than Protestants. ${ }^{38}$ As late as the 1840 s, five states still had restrictions on political rights for Jews. The last two states to lift the requirement to belong to a Protestant Confession in order to access political rights were North Carolina in 1868, and New Hampshire in 1877. ${ }^{39}$

This gradual codification of religious liberties was a clear expression of American society investing in the idea of religious freedom. But it was not necessarily an expression of the practice of this idea, nor of pluralism being perceived as something positive or enriching. There is reason to believe that the notion of religious freedom was a necessity in the formation of a nation that, from the outset, harboured such great religious differences. The depth of an individual's virtue of tolerance was put to the test, and political authorities at various levels were challenged in their practice of toleration.

An illustrative example is the 4th of July parade in Philadelphia in 1788. Here, 17 priests from a range of denominations - including Catholic priests and Jewish rabbis - walked arm in arm, four in each row. This was starkly sym-

37 Chris Beneke, “The 'Catholic Spirit Prevailing in Our Country': America's Moderate Religious Revolution," in The First Prejudice: Religious Tolerance and Intolerance in Early America, ed. Chris Beneke and Christopher S. Grenda. Early American Studies (Philadelphia, US: University of Pennsylvania Press, 2011), 267.

38 J.K. Wilson, "Religion Under the State Constitutions, 1776-1800," Journal of Church and State, vol. 32, no. 4 (1990): $760 \mathrm{f}$.

39 Beneke, "The 'Catholic Spirit," 284. See also Rafael Medoff, Jewish Americans and Political Participation: A Reference Handbook (Santa Barbara-Denver-Oxford: ABC-Clio, 2002), 76; Stanley F. Chyet, "The Political Rights of the Jews in the United States: 1776-1840," American Jewish Archives Journal, vol. 10, no. 1 (1958); David Sorkin, "Is American Jewry Exceptional?: Comparing Jewish Emancipation in Europe and America," American Jewish History, vol. 96, no. 3 (September 2010). 
bolic and intended to demonstrate and promote harmony, as well as peaceful coexistence, across religious divides. Founding Father Benjamin Rush later remarked that it was intended to emphasise that federal offices and posts were open to all, regardless of religion. ${ }^{40}$ At the same time, however, Rush stressed that this ecumenical episode did not come into being without putting a great deal of strain on the toleration muscle: "Pains were taken to connect Ministers of the most dissimilar religious principles together," he explained. ${ }^{41}$ It was unpleasant to walk hand in hand, but these torments had to be endured for a higher cause - the common good.

Historian David Sehat claims that American religious freedom throughout the 19th century is a myth created by a need to construct an American identity. ${ }^{42}$ He argues that since the United States built its politics upon a Christian morality, the separation between state and religion is a fallacy. The state church was replaced by a binding Christian state morality. Sehat believes that the image of 19th-century America as a state with a singular degree of religious freedom is also a false notion, pointing out the legal and social discrimination against Catholics, Jews, Mormons, and atheists in the judiciary - including the federal Supreme Court - all the way up to the 1920 s. $^{43}$

\section{Religion and politics}

This brief sweep over the conditions for religious toleration and religious freedom in the West in the centuries up to the early 1800s hints at how complex the two have been, both as an idea and as a practice. Freedom of religion was more or less an abstraction, and most often implicitly restricted to certain religious communities, primarily Christians. Toleration was more widespread, but an expression of reluctance and aversion all the same, and was closely linked to religious persecution and to secular and religious power structures.

When it came to what tools should or could be used in the face of religious aversion, there were different points of view. For many it was legitimate to put the instruments of state power to use by denying residence or religious practice to certain groups. It could be accomplished by persecuting those who violated this in various ways, by putting a stop to their religious practice, as well as im-

40 Beneke, Beyond Toleration, 4.

41 Beneke, Beyond Toleration, 5.

42 David Sehat, The Myth of American Religious Freedom. Updated Edition (New York: Oxford University Press, 2016), 7.

43 Sehat, The Myth of American Religious Freedom, 8. 
prisoning, deporting or punishing them. Due to the understanding that one's own doctrines were true and that others stood for false doctrines and heresy, a characteristic even of pluralistic societies was a widespread belief that the right to free religious practice ought to be confined to one's own religion. As such, one could argue for one's own right to religious practice in regions where a religious community constituted a minority, while toleration for other confessions could be highly restricted in regions where the same religious community was hegemonic.

But religious coercion could also be looked upon as undesirable, either on Christian-liberal grounds, upon which compulsion was considered to run contrary to Christian values, or because coercion, by creating martyrs that emboldened dissenters rather than combatted them, was perceived to be counterproductive. Coercive means could also be considered illegitimate for secular and liberal reasons in which religion was considered private and therefore not something that political authorities ought to restrict. Rooted in liberal ideas, more and more people therefore began to view religious freedom as a human right. This perspective built in strength, notably from the end of the 18th century.

Theological arguments could be put forward against permitting dissenting religions, especially in religiously homogeneous states. To protect citizens from religious apostasy was to protect their souls from eternal damnation and doom. However, the most vital criterion in determining which religions and religious practices could not be tolerated was above all a political-moral assessment of whether they were in conflict with the laws of the land or the prevailing mores and morals of the state and society. Such religious communities were widely perceived as a danger to the state and to society's very existence, and were therefore labelled as undesirable, and frequently as something that ought to be fought back.

There was, of course, also an additional political dimension here. Monarchical absolutism was closely connected to the practice of religion, and naturally, religion and the doctrines of the state church was one and the same; in the case of Denmark-Norway and Sweden, this was the Evangelical Lutheran religion, built on the Augsburg Confession of 1530. Christian V's Danish and Norwegian Codes (1683 and 1687 respectively) stated that within the dual monarchy, only this was a lawful religion. The absolute monarch's Lex Regia stated not only that the king and his descendants would confess it, but also that religious unity among the people was desirable. ${ }^{44}$

44 Christian V's Norwegian Code of 1687, 2-1-1. Lex Regia of 1665, Article I. It can also be argued that the desire for religious unity has parallels with expectations for linguistic unity of 
The state was given the role of protector of the religion, while the religion was to support the state and sovereign. ${ }^{45}$ For some state theorists during the period of absolute monarchy, it was precisely the safeguarding of the religion that was the state's most important objective. Through Professor (later Bishop) Erik Pontoppidan's (1698-1764) explanation from 1737, for example, it was impressed upon young confirmands in Denmark-Norway that subjects were to honour and obey authority. ${ }^{46}$ Being loyal and obedient to the king entailed being a good Christian, and vice versa. Norwegian historian Øystein Rian has drawn a particularly strong connection between king and God in the sermon. According to him, the message was that if one opposed the king, it would be impossible to be considered a Christian with any prospect of salvation: "Allegiance and obedience to him were an absolute requirement." 47

At the same time, being a good Christian was also seen as a prerequisite for being qualified for inclusion in the polity, both religiously and civically. The mandatory affirmation of baptism through confirmation was a condition for access to both rights and obligations, such as entering into marriage, military service and the swearing of oaths. Belonging to the state religion was not only a condition of being a member of a religious community, but a legally warranted requirement in order to be regarded as a competent, responsible and authoritative member of society in general. ${ }^{48}$

Churches - and their pulpits - were vital to the absolute monarchy's propaganda apparatus and were key to the state's social and political control. Religious pluralism not only weakened the monarchy's strict disciplinarian hold on the population, but also provided fertile ground for conflicts internal to the

more recent times, in the sense that mastery of the local language is viewed as a condition for citizenship and participation in the national community. In the same way as the use of forcible means to achieve religious unity was legitimate under absolutism, the demand for mastery of the language is essentially viewed as a legitimate use by the state of forcible means in more recent times.

45 See Øystein Rian, Sensuren i Danmark-Norge: Vilkårene for offentlige ytringer 1536-1814 (Oslo: Universitetsforlaget, 2014); Øystein Lydik Idsø Viken, Frygte Gud og ære Kongen: preikestolen som politisk instrument i Noreg 1720-1814. PhD dissertation (Oslo: University of Oslo, 2014); Berge Furre, "Hans Nielsen Hauge - stats- og samfunnsfiende," in Moralsk og moderne?: Trekk av den kristne moraltradisjon i Norge fra 1814 til i dag, ed. Svein Aage Christoffersen (Oslo: Ad notam Gyldendal, 1999); Per Kristian Aschim, "Religion og stat i statsteoretisk litteratur i Danmark-Norge før 1814,” Historisk Tidsskrift, vol. 94, no. 4 (2015): 593.

46 Quoted here from Furre, "Hans Nielsen Hauge,” 82.

47 Rian, Sensuren i Danmark-Norge, 630.

48 Arne Bugge Amundsen, "Fromme Borgeres Vindskibelighed og Dyd," in Konfirmasjonen i går og i dag: Festskrift til 250-års jubileet 13. Januar 1986, ed. Brynjar Haraldsø (Oslo: Verbum, 1986), 244. 
populace and between the people and the sovereign. This was also addressed in state theory literature as early as the 17th century. Political philosopher Samuel Pufendorf (1632-1694) pointed out that since pluralism often led to unrest, a singular state religion was considered "the greatest Happiness of a Government." For Pufendorf, religious unity was advantageous, but all the same no proviso for the avoidance of domestic turmoil. ${ }^{49}$ In Sweden, too, ever since the first part of the 17th century, religious unity had been explicitly considered as the most important foundation of a harmonious and lasting system of government. ${ }^{50}$

It was such notions that the Norwegian "constitutional father" Wilhelm Frimann Koren Christie (1778-1849) was depending on when, at Eidsvoll in 1814, he proposed to confine religious freedom to Christians alone. The state ought not to anticipate any benefit from permitting non-Christian public worship unhindered; "on the contrary, great Danger thereof may be feared." Charlatans could, "under the Disguise of Sanctity and religious Fervour, simply help themselves to the People's Wealth and lure them towards Vices, Rebellion against the Authorities of the Country, etc.," Christie proffered. ${ }^{51}$ And perhaps this, too, was the explanation for the adopted wording on religious freedom for Christians vanishing entirely when the time came to ratify the Constitution. ${ }^{52}$

It was commonplace in the 1600s and 1700s to regard religious heterodoxy as a threat, and it was chiefly this that set the stage for religious policy in religiously homogeneous states. Scandinavia itself stood out as a religiously homogeneous region of Europe, alongside the Iberian Peninsula, Italy and central Russia.

It is a crucial point that even those voices that argued most eagerly for religious toleration - such as Locke at the beginning of the Enlightenment, and subsequently Rousseau (Du contrat social, 1762) and Voltaire (Traité sur la tolérance, 1763) - did not do so without reservation. ${ }^{53}$ Religious freedom had its boundary

49 Samuel Pufendorf, of the Nature and Qualification of Religion, In Reference to Civil Society. Translated from the Original (London:, 1698), 130. See also p. 14. The work was published in Latin in 1687 ("the greatest Happiness of a Government").

50 Winton, "Enighetens befrämjande," $5 \mathrm{ff}$.

51 Eli Fure, Eidsvoll 1814: Hvordan Grunnloven ble til (Oslo: Dreyers forlag, 1989), 129.

52 Berge Furre, "Kva skjedde med religionsfridomen på Eidsvoll 1814?," in Rettsteori og rettsliv: Festskrift til Carsten Smith til 70-årsdagen 13. juli 2002, ed. Peter Lødrup et al. (Oslo: Universitetsforlaget, 2002). Furre first put forward this point of view on the Norwegian Broadcasting Corporation radio programme P2-Akadiemiet in 1993.

53 Jean-Jacques Rousseau, The Social Contract \& Discourses (London-Toronto: J.M. Dent \& Sons, 1920 [1761]), 121: "There is therefore a purely civil profession of faith of which the Sovereign should fix the articles, not exactly as religious dogmas, but as social sentiments without which a man cannot be a good citizen or a faithful subject. While it can compel no one to believe 
line, and not all could be tolerated. This was especially true when aberrant religions were understood to represent a kind of peril to society and the state. This also received support in Danish-Norwegian political philosophy of the late 18th century. ${ }^{54}$

Common to Jews, Mormons and Jesuits was the allegation that they represented a disloyal and untrustworthy state within the state, one that conspired via immoral means to a kind of theocratic project that would cause social and political upheaval. It is here, too, that the essence of their alleged political danger lies. For that reason, in what follows I will look more closely at how the concept of "state within the state" proliferated and eventually became central not only to the argument for denying religious freedom to Jews, Mormons and Jesuits, but also to why these groups could not be tolerated.

them, it can banish from the State whoever does not believe them-it can banish him, not for impiety, but as an anti-social being, incapable of truly loving the laws and justice, and of sacrificing, at need, his life to his duty. If any one, after publicly recognising these dogmas, behaves as if he does not believe them, let him be punished by death: he has committed the worst of all crimes, that of lying before the law."; Voltaire, The Works of M. de Voltaire: A treatise on toleration, vol. 34 (London, 1764); Chap XVIII. The only Cases in which Non-Toleration makes Part of the Human Law (p. 214): "For a government not to have a right to punish men for their errors, it is necessary that those errors should not be crimes; and they are crimes only when they disturb the public tranquility; which they do whenever they inspire enthusiasm: it is necessary therefore that men should begin by laying aside enthusiasm, in order to deserve toleration."

54 See Aschim, "Religion og stat," for a good discussion of the points of view of state theorists such as Christian Fabricius (1745-1808), Lauritz Nørregaard (1745-1804), Johan Friedrich Wilhelm Schlegel (1765-1836) and Anders Sandøe Ørsted (1778-1860). 